\title{
Potted rose cultivars with paclobutrazol drench applications
}

\author{
Maristela Pereira Carvalho-Zanão ${ }^{1} \cdot$ Luiz Antônio Zanão Júnior $^{1^{*}}$ \\ José Antonio Saraiva Grossi ${ }^{2}$ () Natalia Pereira $^{3} \odot$
}

${ }^{1}$ Instituto Agronômico do Paraná (IAPAR), 85825-000, Santa Tereza do Oeste, PR, Brasil. E-mail: 1zanao@iapar.br. "Corresponding author. ${ }^{2}$ Departamento de Fitotecnia, Universidade Federal de Viçosa (UFV), Viçosa, MG, Brasil.

${ }^{3}$ Departamento de Pós-graduação em Engenharia Agrícola, Universidade Estadual do Oeste do Paraná (UNIOESTE), Cascavel, PR, Brasil.

\begin{abstract}
Growth retardants, such as paclobutrazol, reduce plant height, and thus enable commercialization of larger ornamental plants in pots. The aim of this research was to evaluate the size, yield and flower quality of two rose cultivars as a function of various paclobutrazol applications to growing substrate. Treatments consisted of two cultivars (Yellow Terrazza ${ }^{\mathbb{B}}$ and Shiny Terrazza ${ }^{\mathbb{P}}$ ) planted in plastic pots and five paclobutrazol doses $\left(0,0.5,1.0,1.5\right.$, and 2.0mg pot $\left.{ }^{-1}\right)$. The experiment was carried out in a greenhouse. Experimental design was randomized blocks with four replications. The following traits were evaluated: plant height; stem diameter, number of flowers and leaves of floral stem; length of flower bud; floral cycle, leaf area; flower diameter and floral longevity; chlorophyll content in leaves; and yield. Paclobutrazol improved the quality and esthetics of flowers of both cultivars. It also reduced leaf dry matter production, plant height, flower height and diameter and increased chlorophyll content and flower longevity. Paclobutrazol effectively reduced plant height, producing a harmonious relationship between the plant and the pot, without phytotoxicity. Therefore, we suggested applying 2.0mgpot ${ }^{-1}$ of paclobutrazol to the substrate of Yellow Terrazza $a^{\circledR}$ and Shiny Terrazza ${ }^{\circledR}$ rose cultivars.

Key words: Rosa hybrid L.; growth retardant; floriculture.
\end{abstract}

Produção de roseiras em vaso com aplicação de paclobutrazol no substrato

RESUMO: A aplicação de retardantes de crescimento, como o paclobutrazol, reduz a altura das plantas e tem possibilitado a comercialização de algumas espécies ornamentais de maior porte em vasos. Objetivou-se com este estudo avaliar porte, produção e qualidade da flor de duas cultivares de roseira cultivadas em vaso em função da aplicação de doses de paclobutrazol no substrato. Os tratamentos foram dispostos em esquema fatorial 2x5, com duas cultivares de roseira (Yellow Terrazza ${ }^{\mathbb{B}}$ e Shiny Terrazza ${ }^{\mathbb{B}}$ ) e cinco doses de paclobutrazol (0; 0,5; 1,0; 1,5 e 2,0 $\mathrm{mg}^{\text {vaso }}{ }^{-1}$ ). O experimento foi conduzido em vasos plásticos sob ambiente protegido, em delineamento de blocos ao acaso com quatro repetições. Foram avaliados a altura das plantas; diâmetro, número de flores e folhas da haste floral; comprimento do botão floral; ciclo, área foliar; diâmetro floral e longevidade floral; teor de clorofila nas folhas e produção. A aplicação de paclobutrazol no substrato proporcionou melhoria na qualidade floral e estética de ambas cultivares de roseira. Também reduziu a produção de matéria seca foliar, altura da planta e diâmetro floral e aumentou o teor de clorofila e a longevidade floral. O paclobutrazol foi eficiente em reduzir a altura, conferindo uma relação harmoniosa entre a planta e o vaso, sem causar sintomas de toxidez e alterações morfológicas. Sugere-se a aplicação no substrato de 2 mg vaso $^{-1}$ de paclobutrazol para as cultivares de roseira Yellow Terrazza $a^{\circledR}$ e Shiny Terrazza $a^{\circledR}$ produzidas em vasos.

Palavras-chave: Rosa hybrida L.; retardante de crescimento; floricultura.

\section{INTRODUCTION}

Rose is an ornamental plant, which to be marketed in pots should have small size. There are miniroses that are naturally small and are well accepted in the market; however, for medium-sized roses $(30-60 \mathrm{~cm})$, size reduction with growth retardants is an alternative.

There are various physiological and morphological responses in plants treated with growth retardants, such as: reduced height, augmented root growth, improved plant architecture, increased levels of chlorophyll, changes in leaf anatomy, longer cycle, reduced leaf area, increased antioxidant potential, increased production of alkaloids, and changes in gas exchange (JALEEL et al., 2007; MAO et al., 2014). Depending on the dose of the retardant and the plant species, phytotoxicity, chlorosis, and leaf or flowers deformation may occur (RADEMACHER, 2015).

Growth retardants, such as paclobutrazol (PBZ), are important tools in floriculture that help obtain smaller plants with proper size for commercialization in pots. According to RADEMACHER (2016), these chemicals affect plant metabolism by inhibiting the 
production of natural gibberellins, which are responsible for cell elongation, thus controlling plant height.

Paclobutrazol is a chemical compound within the group of triazoles. It is characterized by high chemical activity in almost all species of ornamental plants. It is registered in Europe and North America (GROSSI et al., 2009). Compact plants with suitable height for commercialization in pots are obtained after applying PBZ to species like cloves, zinnia, iris, lily and sunflower (PINTO et al., 2005; AL-KHASSAWNEH et al., 2006; FRANCESCANGELI et al., 2007; BARBOSA et al., 2009).

The most common application methods of growth retardants are foliar sprays and media drench. Paclobutrazol shows good results for both methods (RADEMACER, 2015); however, drenches act longer and provide uniform control of plant height with lower doses (FRANÇA, et al., 2017).

Efficacy of growth retardants may vary within cultivars of the same species (WHIPKER \& MCCALL, 2000). Therefore, it is important to optimize their use by selecting adequate dosage, cultivars, production conditions, and the desired effect (COCHRAN \& FULCHER, 2013). For that, it is important to evaluate the effect of paclobutrazol on different species, even cultivars, to check if there are any morphological changes that may impede its use and whether obtained plant size is suitable for commercialization in pots.

Thus, the aim of this study was to assess the size, production and quality of flowers of two rose cultivars grown in pots on substrate amended with paclobutrazol.

\section{MATERIALS AND METHODS}

The experiment was conducted in a greenhouse from October to December, 2008. During that period, the minimum and maximum daily average temperatures were $17.3^{\circ} \mathrm{C}$ and $33.9^{\circ} \mathrm{C}$ respectively, and day and night relative average humidity was $65.6 \%$ and $85.5 \%$, respectively. The plants were kept under natural photoperiod and received the same amount of water and fertilizer.

Treatments consisted of two rose cultivars 'Yellow Terrazza ${ }^{\circledR}$ ' (YT) and 'Shiny Terrazza ${ }^{\circledR}$ ' (ST), and five paclobutrazol doses applied to the substrate $\left(0,0.5,1.0,1.5,2.0 \mathrm{mg}\right.$ pot $\left.^{-1}\right)$. The experimental design was randomized blocks with four replications. Each experimental block consisted of one plant. The active ingredient -paclobutrazol- was obtained from a commercial product Cultar ${ }^{\circledR}$ (25\% paclobutrazol).

Paclobutrazol drenches were split into two applications: first was carried out when the plants reached $1-2 \mathrm{~cm}$ and the other $3-5 \mathrm{~cm}$, based on the results of the previous assay.

Yellow Terrazza ${ }^{\circledR}$ has an average height of $45 \mathrm{~cm}$, produces up to three (or more) flowers per stem of an average diameter of $7 \mathrm{~cm}$ with colors ranging from yellow cream to white. Shiny Terrazza ${ }^{\circledR}$ has an average height ranging from 40 to $45 \mathrm{~cm}$, with yellow flowers of an average diameter of $8 \mathrm{~cm}$. Young plants with two flower stalks were individually transplanted into plastic pots No. 12 , $\left(10 \mathrm{~cm}\right.$ high and $800 \mathrm{~cm}^{-}$ ${ }^{3}$ volume capacity) containing $0.6 \mathrm{~kg}$ of Plantmax ${ }^{\circledR}$ substrate based on pine bark and vermiculite. Pots were spaced $25 \times 25 \mathrm{~cm}$ apart on benches. After transplanting and acclimatization, plants underwent pruning down to two stems.

Plants were irrigated daily. Fertigation was performed twice a week, applying $100 \mathrm{~mL}^{-}$pot $^{-}$ ${ }^{1}$ of $1.4 \mathrm{~g} \mathrm{~L}^{-1}$ of Peters ${ }^{\circledR}$ fertilizer $(\mathrm{NPK}+\mathrm{Ca}+\mathrm{Mg}+$ micronutrients), providing the following nutrients and their amounts $\left(\mathrm{mg} \mathrm{L}^{-1}\right)$ : N- 200; $\mathrm{P}-29.4 ; \mathrm{K}$ - 166, Ca - 66,6; Mg - 26.6; B - 0.2; Cu - 0.094; $\mathrm{Fe}-1.0 ; \mathrm{Mn}-0.494 ; \mathrm{Mo}-0.094$, and $\mathrm{Zn}-0.532$, according to CARVALHO-ZANÃO et al. (2017). Assessments were made using the scale proposed by CUSHMAN et al. (1994) for floral opening stages, which characterizes each stage as: (1) closed bud, (2) petals closed and sepals open, (3) early opening of petals (traditional flower bud stage), (4) several petals open, (5) fully open (6) end of vase life (wilting and/ or dimming of one petal) (Figure 1).

The following traits were evaluated at stage 2: plant height (measured from the top edge of the pot to end of the flower bud), stem diameter, and number of leaves and flowers per flowering stem. Later, flower bud length was evaluated at stage 3 and flower diameter at stage 5 .

The cycle was determined by counting days between pruning and stage 2 , and floral longevity by counting days between stage 2 and stage 6 . After stage 6, leaf area was evaluated using the MK2 meter (AT Delta-T Devices).

To determine dry matter, leaves, flowers and roots were detached from plants, washed and dried in oven with forced air circulation at $70^{\circ} \mathrm{C}$ until they reached constant mass.

The determination of total chlorophyll content was performed using the colorimetric method described by PORRA et al. (1989), with $80 \%$ acetone as extractor. The leaves were taken from the middle third of the stem of plants with flower at stage 6 .

The data were submitted to analysis of variance. The effects on the cultivars were evaluated by $\mathrm{F}$ test at $5 \%$ probability, and PBZ doses by 


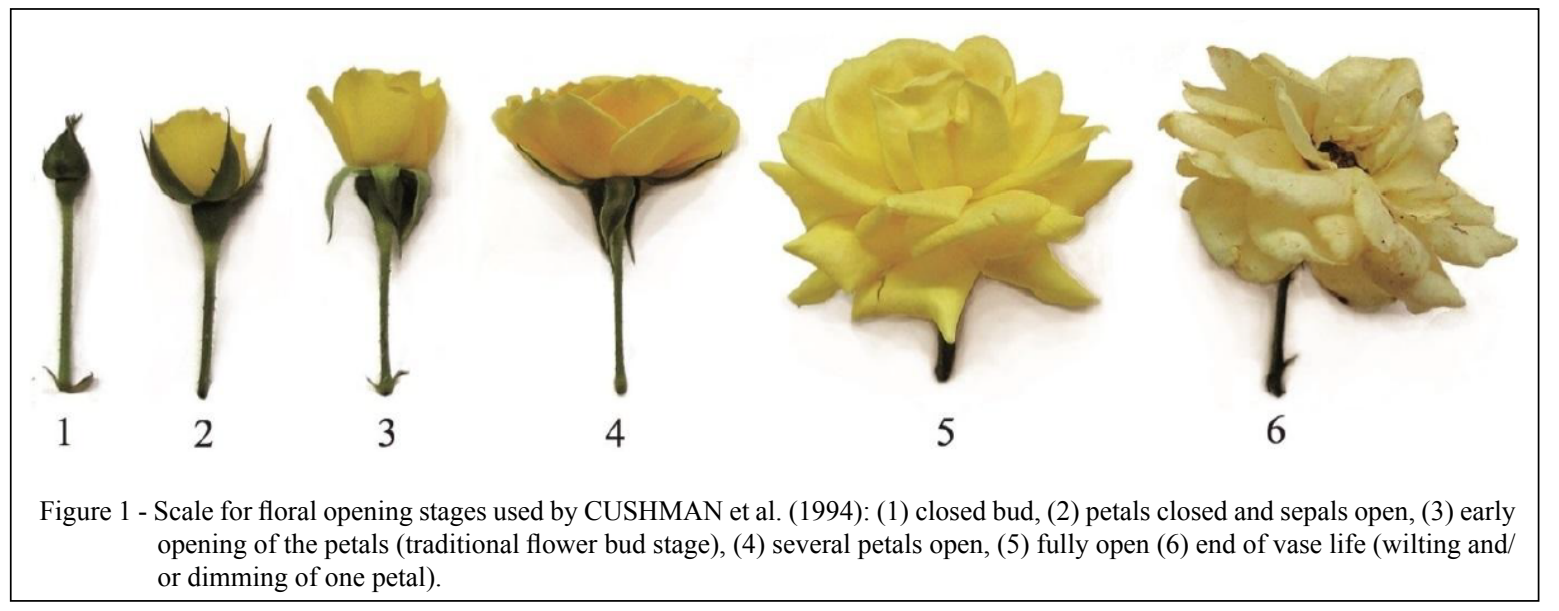

regression analysis, with coefficients tested up to $5 \%$ probability error by the t test.

\section{RESULTS AND DISCUSSION}

Both rose cultivars did not differ in: the number of leaves and flowers per floral stem, production cycle, dry matter of flowers, and flower diameter (Table 1). Plants produced about ten leaves and two flowers with $8.2 \mathrm{~cm}$ in diameter per stem; their cycle was around 50 days and flower dry matter $1.7 \mathrm{~g}$ plant $^{-1}$.

Shiny Terrazza produced taller plants, with more leaf area and dry matter of leaves and roots relative to Yellow Terrazza. However, Yellow Terrazza produced thicker flower stems-longer floral bud, more durable flowers and higher chlorophyll content in leaves (Table 1).

No interaction between the evaluated traits was observed for measured variables, which means that the effect of the retardant did not depend on the cultivar. The PBZ doses linearly reduced plant height with increasing retardant doses

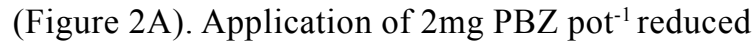
plant height by $27 \%(7.3 \mathrm{~cm})$ relative to the control. Similar results were observed by AHMAD et al. (2014) who studied doses of the same retardant in sunflower and zinnia.

Table 1 - Plant height; flowering stem diameters; number of leaves and flowers per flowering stem; cycle; flower bud length; flower diameter; floral longevity; leaf area; total chlorophyll content; and dry matter production of leaves, flowers and roots of two rose cultivars as a function of paclobutrazol doses applied to the growing substrate $(n=20)$.

\begin{tabular}{|c|c|c|c|}
\hline Production components & Yellow Terrazza & Shiny Terrazza & $\mathrm{CV} \%$ \\
\hline Plant height, $\mathrm{cm}$ & $21.13 b$ & $23.06 \mathrm{a}$ & 12.61 \\
\hline Flowering stem diameters, $\mathrm{cm}$ & $0.27 \mathrm{~b}$ & $0.31 \mathrm{a}$ & 9.93 \\
\hline Leaves per flowering stem & $10.0 \mathrm{a}$ & $9.7 \mathrm{a}$ & 11.58 \\
\hline Leaf area, $\mathrm{cm}^{2}$ & $150.01 b$ & $246.15 \mathrm{a}$ & 11.92 \\
\hline Flowers per flowering stem & $2.00 \mathrm{a}$ & $2.00 \mathrm{a}$ & 10.97 \\
\hline Dry matter production of leaves, $\mathrm{g}_{\text {plant }}{ }^{-1}$ & $1.11 \mathrm{~b}$ & $2.12 \mathrm{a}$ & 15.03 \\
\hline Dry matter production of flowers, $g$ plant ${ }^{-1}$ & $1.70 \mathrm{a}$ & $1.74 \mathrm{a}$ & 6.08 \\
\hline Dry matter production of roots, $\mathrm{g}$ plant ${ }^{-1}$ & $1.81 \mathrm{~b}$ & $3.35 \mathrm{a}$ & 18.45 \\
\hline Floral cycle, $\mathrm{d}$ & $48.60 \mathrm{a}$ & $50.15 a$ & 6.43 \\
\hline Flower bud length, cm & $3.18 \mathrm{a}$ & $2.87 \mathrm{~b}$ & 5.00 \\
\hline Flower diameter, cm & $8.17 \mathrm{a}$ & $8.16 \mathrm{a}$ & 3.83 \\
\hline Floral longevity, d & $9.45 \mathrm{a}$ & $8.35 b$ & 10.50 \\
\hline Total chlorophyll content, $\mathrm{mg} \mathrm{L}^{-1}$ & $4.24 \mathrm{a}$ & $3.65 b$ & 7.23 \\
\hline
\end{tabular}

Mean values followed by different letters in the column differ at $5 \%$ probability by $\mathrm{F}$ test. 


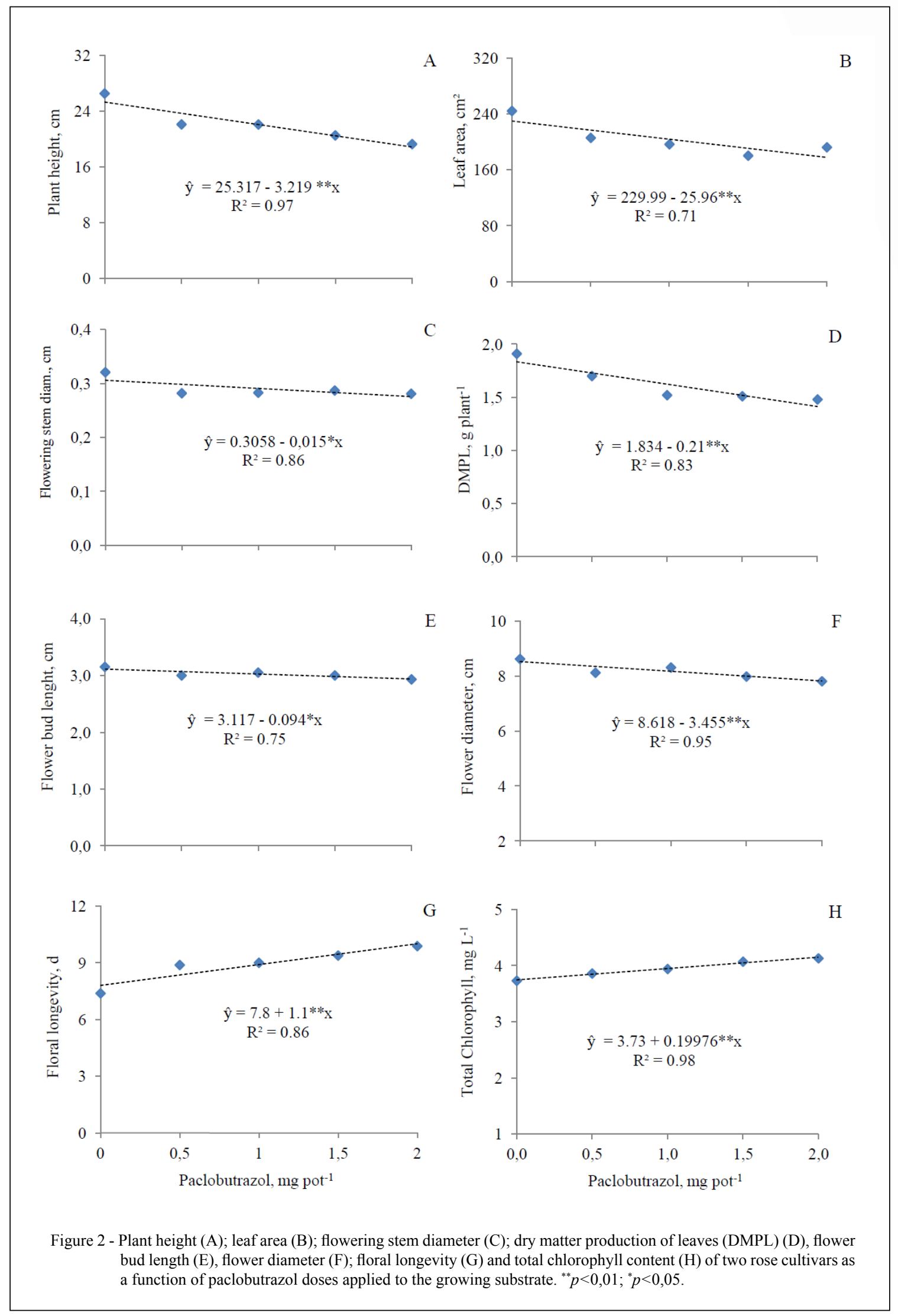

Ciência Rural, v.48, n.8, 2018. 
Height reduction of ornamental plants caused by PBZ has been observed by some authors in herbaceous plants. Doses ranging from 0.025 to $2 \mathrm{mg} \mathrm{pot}^{-1}$ produced satisfactory results according to PINTO et al., 2005; ALKHASSAWNEH et al., 2006; HWANG et al., 2008.

According to BARROSO et al. (2012), harmony between the plant and the pot is achieved when the height of the plant is 1.5 to 2 times the height of the pot, i.e., between 15 and $20 \mathrm{~cm}$ for plants grown in pots of $10 \mathrm{~cm}$, as in the present research. This ideal height was obtained in this study with $2.0 \mathrm{mg}$ PBZ pot $^{-1}$, resulting in plants with height of $19 \mathrm{~cm}$.

Leaf area and stem diameter decreased linearly with increasing PBZ doses (Figures 2B and 2C). Reduction of leaf area and plant height with PBZ doses has also been observed by NAVARRO et al. (2007) in Arbustus unedo, HWANG et al. (2008) in Kalanchoe blosfeldiana cv. Gold Strike, and SINGH et al. (2016) in Pelargonium x hortorum.

Paclobutrazol causes growth reduction by inhibiting gibberellin biosynthesis, which expands and elongates meristematic cells in the internodes (TAIZ \& ZEIGER, 2004). This fact probably explains the reduction of plant height, stem diameter, and leaf area.

PBZ drench did not affect the number of leaves on the flowering stem $(\hat{y}=9.85$ leaves $)$. This fact was also reported by PINTO et al. (2005) and Al-KHASSAWNEH et al. (2006), who reported no effect of PBZ on the number of leaves in zinnia and iris, respectively. However, the effect of PBZ seems to depend on plant species and retardant dose, as an increase in the number of leaves in Kalanchoe (HWANG et al., 2008) and sunflower (BARBOSA et al., 2009) and reduction in Arbutus unedo (NAVARRO et al., 2007), were observed after PBZ applications.

Increasing PBZ dose reduced dry matter of leaves linearly (Figure 2D). This fact is due to reduced plant height and leaf area. Similar reduction of foliar dry matter with PBZ doses was also reported in zinnia (PINTO et al., 2005) and summer tulip (PINTO et al., 2006).

Dry matter production of flowers was not correlated with PBZ doses $(\hat{y}=1.72)$. But, probably there was more carbon partitioning in flowers with PBZ doses, because a reduction of dry mass of leaves without changing dry matter production of flowers was observed. According to KUMAR et al. (2012) and MABVONGWE et al. (2016), paclobutrazol can change partitioning of assimilates in favor of reproductive organs, such as flowers, in to the detriment of vegetative organs, such as leaves.

Dry matter production of roots was not correlated with PBZ doses $\left(\hat{y}=2.62 \mathrm{~g} \mathrm{plant}^{-1}\right)$.
WILKINSON \& RICHARDS (1987) report that the growth of the root system can be reduced if the media drench contains high paclobutrazol concentration, which did not occur in this study.

Increasing PBZ doses reduced bud length and flower diameter linearly (Figures $2 \mathrm{E}$ and $2 \mathrm{~F}$, respectively). Reduction of flower diameter was subtle $-0.8 \mathrm{~cm}$ on average- compared to the control. Therefore, doses did not sabotage the commercial aspect of the flowers. YAO \& FINLAYSON (2015) also observed that the use of growth regulator reduced the bud length in Arabidopsis thaliana and WANDERLEY et al. (2014) also observed reduced diameter of sunflower inflorescence and genotypic differences caused by PBZ drench applications. It is noteworthy that PBZ reduced plant size without changing the quality of flower, rendering more harmonic plants in relation to the pot. There were no deformations of buds and flowers at administered doses.

Floral cycle and the number of flowers per stem were not affected by PBZ doses. On average, plants bloomed after 49.4 days and produced two flowers per stem. In ornamental plants, growth retardants often control the height without affecting flowering (BASRA, 2000). Regarding the number of flowers, it seems that this trait is affected by plant species, the retardant, and its dose. SINGH et al. (2016) obtained the highest number of flowers per plant with PBZ applied to geranium.

Floral longevity increased linearly with PBZ doses (Figure 2G). The highest dose of PBZ extended flower longevity by 2.5 days relative to the control. FRANCESCANGELI \& ZAGABRIA (2008) reported increased floral longevity of petunia with $\mathrm{PBZ}$ doses; however, SINGH et al. (2016) observed reduced floral longevity of geraniums. According to OLSEN \& ANDERSEN (1995), growth retardants generally reduce flower longevity, but it depends on the dose, species, and the retardant. These authors found that PBZ did not alter floral longevity of cape marguerite (Osteospermum ecklonis cv. Calypso), but uniconazol, chloride chlormequat and flurprimidol did.

Total chlorophyll content was significantly correlated with PBZ dose (Figure 2H). Increasing PBZ dose produced linear increase of total chlorophyll. This effect has already been observed by JALEEL et al. (2007), TANNIS et al. (2015) and CARVALHO et al. (2016). Chlorophyll content increased due to elevated production of endogenous cytokinin with the application of PBZ, which enhances differentiation of chloroplasts, chlorophyll synthesis and prevents its degradation (FLETCHER et al., 2000). In addition, 
plant cells treated with PBZ are smaller with low chlorophyll concentration and reduced intercellular space (CATHEY, 1975). According to BARBOSA et al. (2009), the contrast between the green of the leaves and the flowers, due to increased chlorophyll content after applying paclobutrazol, increases visual attractiveness of plants; and consequently, facilitates their commercialization.

\section{CONCLUSION}

Paclobutrazol drench application improves floral quality and aesthetics of rose cultivars Yellow Terrazza ${ }^{\mathbb{B}}$ and Shiny Terrazza ${ }^{\mathbb{B}}$ by reducing their height and providing harmonious relationship between plant and pot without causing toxic symptoms and floral deformation. Suggested paclobutrazol on drench dose is $2 \mathrm{mg} \mathrm{pot}^{-1}$ for Yellow Terrazza ${ }^{\circledR}$ and Shiny Terrazza ${ }^{\circledR}$ cultivars.

\section{CONFLICTS OF INTEREST}

The authors declare no conflict of interest. The founding sponsors had no role in the design of the study; in the collection, analyses, or interpretation of data; in the writing of the manuscript, and in the decision to publish the results.

\section{REFERENCES}

AL-KHASSAWNEH, N.M. et al. Growth and flowering of black iris (Iris nigricans Dinsm.) following treatment with plant growth regulators. Scientia Horticulturae, v.107, p.187-193, 2006. Available from: <http://www.sciencedirect.com/science/article/pii/ S0304423805003304>. Accessed: Nov. 2, 2016. doi: 10.1016/j. scienta.2005.10.003.

AHMAD, I. et al. Paclobutrazol and ancymidol lower water use of potted ornamental plants and plugs. European Journal of Horticultural Science, v.79, p.318-326, 2014. Available from: $<\mathrm{http} / /$ www.pubhort.org/ejhs/2014/4999800.htm>. Accessed: Nov. 2, 2016.

BARBOSA, J.G. et al. Cultivation of ornamental sunflower (Helianthus annuus L.) in vase under diferentes paclobutrazol doses. Revista Brasileira de Horticultura Ornamental, v.14, p.205-208, 2009. Available from: $<$ http://www.scielo.br/scielo.php?script $=$ sci arttext\&pid=S0034-737X2014000100005>. Accessed: Nov. 2, 2016. doi: 10.1590/S0034-737X2014000100005.

BARROSO, P.A. et al. Analysis of segregating generation for components of seedling and plant height of pepper (Capsicum annuum L.) for medicinal and ornamental purposes. Acta Horticulturae, v.953, p.269-276, 2012. Available from: <https://www.actahort.org/ books/953/953_37.htm>. Accessed: Jan. 19, 2018. doi: 10.17660/ ActaHortic.2012.953.37.

BASRA, A.S. Plant growth regulators in agriculture and horticulture: their role and commercial uses. New York: Food Products Press, 2000. 1ed.

CARVALHO, M.E.A. et al. Are plant growth retardants a strategy to decrease lodging and increase yield of sunflower? Comunicata
Scientiae, v.7, p.154-159, 2016. Available from: <https:// comunicatascientiae.com.br/comunicata/article/view/1286>. Accessed: Nov. 2, 2016. doi: 10.14295/cs.v7i1.1286.

CARVALHO-ZANÃO, M.P. et al. Production and leaf plasticity of rose plants sprayed with paclobutrazol and daminozide. Semina: Ciências Agrárias, v.38, p.3481-3490, 2017. Available from: <http://www. uel.br/revistas/uel/index.php/semagrarias/article/view/28424/22256>. Accessed: Dec. 31, 2017. doi: 10.5433/1679-0359.2017v38n6p3481.

CATHEY, H.M. Comparative growth retarding activities of acymidol, AMO-1618, phophon, chlormequat and SADH on ornamental plant species. HortScience, v.10, p.204-216, 1975. Available from: <http:// kbd.kew.org/kbd/detailedresult.do?id=47514>. Accessed: Nov. 2, 2016.

COCHRAN, R.C.; FULCHER, A. Type and rate of plant growth regulator influence vegetative, floral growth, and quality of little Lime ${ }^{\mathrm{TM}}$ Hydrangea. Hort Technology, v.23, p.306-311, 2013. Available from: <http://horttech. ashspublications.org/content/23/3/306.full >. Accessed: Nov. 2, 2016.

CUSHMAN, L.C. et al. Cultivar, flower stage, silver thiosulfate, and BA interactions affect performance of potted miniature roses. Hort Science, v.29, p.805-808, 1994. Available from: <http://hortsci.ashspublications. org/content/29/7/805.full.pdf $>$. Accessed: Nov. 2, 2016.

FLETCHER, R.A. et al. Triazoles as plant growth regulators and stress protectants. Horticultural Reviews, v.24, p.55-138, 2000. Available from: <http://onlinelibrary.wiley.com/doi/10.1002/9780470650776.ch3/ summary>. Accessed: Nov. 2, 2016. doi: 10.1002/9780470650776.ch3.

FRANÇA, C.F.M. et al. Evaluation of paclobutrazol application method on quality characteristics of ornamental pepper. Ornamental Horticulture, v.23, p.307-310, 2017. Available from: <https:// ornamentalhorticulture.emnuvens.com.br/rbho/article/view/1074>. Accessed: Jan. 17, 2018. doi: 10.14295/oh.v23i3.1074.

FRANCESCANGELI, N. et al. Paclobutrazol for height control of two Lilium L.A. hybrids grown in pots. Spanish Journal of Agricultural Research, v.5, p.425-430, 2007. Available from: $<$ http://revistas.inia.es/index.php/sjar/article/view/266>. Accessed: Nov. 2, 2016. doi: 10.5424/sjar/2007053-266.

FRANCESCANGELI, N.; ZAGABRIA, A. Paclobutrazol for height control of petunias. Chilean Journal of Agricultural Research, v.68, p.309-314, 2008. Available from: <http://www.bioline.org.br/ abstract?id=cj08032>. Accessed: Nov. 2, 2016. doi: 10.4067/S071858392008000300012 .

GROSSI, J.A.S. et al. Retardantes de crescimento de plantas ornamentais. Informe Agropecuário, v.3, p.33-35, 2009. Available from: <http://www.epamig.br/index.php?option=com_content\&ta $\mathrm{sk}=$ view\&id=1268\&Itemid=220>. Accessed: Nov. 2, 2016.

HWANG, S.J. et al. Suppression of stem growth in pot kalanchoe 'Gold Strike' by recycled subirrigational supply of plant growth retardants. African Journal of Biotechnology, v.7, p.1487-1493, 2008. Available from: <http://www.academicjournals.org/journal/AJB/article-full-textpdf/74706977332>. Accessed: Nov. 2, 2016. doi: 10.5897/AJB08.196.

JALEEL, C.A. et al. Paclobutrazol enhances photosynthesis and ajmalicine production in Catharanthus roseus. Process Biochemistry, v.42, p.1566-1570, 2007. Available from: <http:// fulltext.study/preview/pdf/35723.pdf $>$. Accessed: Nov. 2, 2016. doi: 10.1016/j.procbio.2007.08.006.

KUMAR, S. et al. Paclobutrazol treatment as a potential strategy for 
higher seed and oil yield in field-grown camelina sativa L. Crantz, BMC Research Notes, v. 137, p. 1-13, 2012. Available from: $<$ https://www.ncbi.nlm.nih.gov/pmc/articles/PMC3320555/>. Accessed: Jan. 18, 2018. doi: 10.1186/1756-0500-5-137.

MABVONGWE, O. et al. The effect of paclobutrazol application time and variety on growth, yield, and quality of potato (Solanum tuberosum L.), Advances in Agriculture, Article ID 1585463, 5 pages, 2016. Available from: $<$ https://www.hindawi. com/journals/aag/2016/1585463/>. Accessed: Jan. 18, 2018. doi:10.1155/2016/1585463.

MAO,L.etal.Cropgrowth, lightutilizationand yield ofrelayintercropped cotton as affected by plant density and a plant growth regulator. Field Crops Research, v.155, p.67-76, 2014. Available from: $<$ http://www sciencedirect.com/science/article/pii/S0378429013003274>. Accessed: Jan. 17, 2018. doi: 10.1016/j.fcr.2013.09.021.

NAVARRO, A. et al. Influence of paclobutrazol on water consumption and plant performance of Arbutus unedo seedlings. Scientia Horticulturae, v.111, p.133-139, 2007. Available from: $<$ http://digital.csic.es/handle/10261/16920? mode $=$ full\&locale $=$ en>. Accessed: Nov. 2, 2016. doi: 10.1016/j.scienta.2006.10.014.

OLSEN, W.W.; ANDERSEN, A.S. The influence of five growth retardants on growth and postproduction qualities of Osteospermum ecklonis cv. 'Calypso'. Scientia Horticulturae, v.62, p.263-270, 1995. Available from: $<$ http://www.worldpapercat.com/1758/Article2965464. htm>. Accessed: Nov. 2, 2016. doi: 10.1016/0304-4238(95)00769-P.

PINTO, A.C.R. et al. Growth retardants on development and ornamental quality of potted Lilliput' Zinnia elegans Jacq. Scientia Agricola, v.62, p.337-345, 2005. Available from: $<$ http://www.scielo. $\mathrm{br} /$ scielo.php?script=sci_arttext\&pid=S0103-90162005000400006>. Accessed: Nov. 2, 2016. doi: 10.1590/S0103-90162005000400006.

PINTO, A.C.R. et al. Growth retardants on production of flowering potted thai tulip. Bragantia, v.65, p.369-380, 2006. Available from: $<\mathrm{http}: / /$ repositorio.unesp.br/handle/11449/1459>. Accessed: Nov. 2, 2016. doi: 10.1590/S0006-87052006000300002.

PORRA, R.J. et al. Determination of accurate extinction coefficients and simultaneous equation for assaying chlorophylls a and b extracted with four different solvents: verification of the concentration of chlorophylls standards by atomic absorption spectroscopy. Biochimica et Biophysica Acta, v.975, p.384-394, 1989. Available from: <http:// www.chem.ucla.edu/dept/Faculty/merchant/pdf/Porra_1989.pdf $>$.
Accessed: Nov. 2, 2016. doi: 10.1016/S0005-2728(89)80347-0.

RADEMACHER, W. Plant Growth regulators: backgrounds and uses in plant production. Journal of Plant Growth Regulation, v.34, p. 845-872, 2015. Available from: <https://link.springer.com/ article/10.1007/s00344-015-9541-6>. Accessed: Jan. 17, 2018. doi: 10.1007/s00344-015-9541-6.

RADEMACHER W. Chemical regulators of gibberellin status and their application in plant production. In: HEDDEN, P (ed) Annual plant reviews, vol 49, The Gibberellins. Hoboken: WileyBlackwell, 2016. Cap. 12, p.359-404.

SINGH, B.S.D. et al. Effect of growing media and paclobutrazol on growth, flowering and pot presentability of geranium, Pelargonium $\mathrm{x}$ hortorum LH Bailey. International Journal of Farm Sciences, v.6, p.128-136, 2016. Available from: <http://www.inflibnet.ac.in/ ojs/index.php/IJFS/article/view/4005>. Accessed: Nov. 2, 2016.

TAIZ, L:; ZEIGER, E. Fisiologia vegetal. Porto Alegre: Artmed, 2004. 3.ed.

TANNIS, S.R. et al. Effects of paclobutrazol and fertilizer and the physiology, growth and biomass allocation on three Frazins species. Urban Forestry and Urban Greening, v.14, p.590-598, 2015. Available from: $<$ http://www.sciencedirect.com/science/article/pii/S1618866715000813>. Accessed: Nov. 2, 2016. doi: 10.1016/j.ufug.2015.05.011.

WANDERLEY, C.S. et al. Growth of potted sunflower in response to paclobutrazol. Revista Ceres, v.61, p.035-041, 2014. Available from: <http://search.proquest.com/openview/95288010f0886d00ad b63aa4aa149964/1?pq-origsite $=$ gscholar>. Accessed: Nov. 2, 2016. doi: 10.1590/S1413-70542007000600011.

WHIPKER, B.E.; MCCALL, I. Response of potted sunflower cultivars to daminozide foliar sprays and paclobutrazol drenches. Hort Technology, v.10, p.209-211, 2000. Available from: <http:// horttech.ashspublications.org/content/10/1/209.abstract $>$. Accessed: Nov. 2, 2016.

WILKINSON, R.I.; RICHARDS, D. Effects of paclobutrazol on growth and flowering of Bouvardia humboldtii. Hort Science, v.22, p.444-445, 1987. Available from: <http://www.pakbs.org/ pjbot/PDFs/41(5)/PJB41(5)2323.pdf $>$. Accessed: Nov. 2, 2016.

YAO, C.; FINLAYSON, S.A. Abscisic acid is a general negative regulator of Arabidopsis axillary bud growth. Plant Physiology, v.169, p.611-626, 2015. Available from: <http://www.plantphysiol. org/content/plantphysiol/169/1/611.full.pdf $>$. Accessed: Jan. 19, 